\title{
Human Resources Information Systems Implementation and Influences in Higher Education:
} Evidence From Malaysia

\author{
Ashkan Davarpanah, Universiti Teknologi Malaysia, Malaysia \\ Norshidah Mohamed, Prince Sultan University, Saudi Arabia
}

\begin{abstract}
The research seeks to develop and test a theoretical model to explain the implementation and influences of human resource information systems (HRIS's) for a Malaysian higher education institution. Data was gathered from 103 respondents in the institution using a survey questionnaire. Results show that system factor, through information quality, and institution-based trust, through situational normality and structural assurance, contribute to user satisfaction. User satisfaction and situational normality predict user-perceived HRIS benefits. Findings aid researchers and practitioners in human resource function when explaining user-perceived benefits and satisfaction with HRIS implementation. The research advances understanding of the role of HRIS in supporting human capital performance and enhancing productivity.
\end{abstract}

\section{KEYWORDS}

Human Resource Information Systems, Information Systems Success, Performance Management, Productivity, Survey Research

\section{INTRODUCTION}

Organizations are increasingly pressured to achieve high performance while remaining relevant and sustainable in the market; they invest carefully in human capital and development as nations compete for talent to attain high human capital performance and labor productivity. Human resources (HR) professionals are pressured to align an organization's human capital to strategic and broad organizational goals. Maximizing HR performance requires HR professionals to recognize and discharge their roles. Information technology (IT) has been an enabler of greater productivity of both human resources and organizations, and advancements in IT have brought about computerbased human resources information systems (HRIS). Historically, HRIS is used for recruitment, administration, and separation of employees. Although these processes have not changed markedly, information collection and storage methods evolved with rapid advancements of technology (Kovach, Hughes, Fagan, \& Maggitti, 2002). HRIS comprises modules that structure an organization, such

DOI: 10.4018/IJABIM.2020070105

This article, originally published under IGI Global's copyright on July 1, 2020 will proceed with publication as an Open Access article starting on February 1, 2021 in the gold Open Access journal, International Journal of Asian Business and Information Management (converted to gold Open Access January 1, 2021), and will be distributed under the terms of the Creative Commons Attribution License (http://creativecommons.org/licenses/by/4.0/) which permits unrestricted use, distribution, and production in any medium, provided the author of the original work and original publication source are properly credited. 
as company, location, departments, and organizational change, including terminations and transfers (Chowdhury, Bandhyapadhya, \& Hazra, 2012).

Various components make up HRIS, and an unsuccessful one therefore influences a system's remaining functionalities negatively (Kassim, Ramayah, \& Kurnia, 2012). Organizations face numerous challenges as they implement IT projects. The International Data Corporation (IDC) reports that $25 \%$ of IT projects fail (Gulla, 2012), $20 \%$ to $25 \%$ of projects do not provide a return on investment (ROI), and up to $50 \%$ of projects require a rework of materials. Iijima (2015) suggests that large IT projects in organizations underperform, and thus returns on IT investments have been a concern among researchers and practitioners. Without positive influences of HRIS, HR professionals are unable to discharge their responsibilities and monitor indicators of human capital. Although common, traditional financial indicators, such as ROI, internal rate of return, and net present value, present challenges when evaluating IT investment decisions (Mayfield, Mayfield, \& Lunce, 2003). Many turn to perceptual measures as proxies for success (Law \& Ngai, 2007), and this applies to HRIS. The literature suggests that measuring the success of IT investments is emphasized when integrating business processes (Mahapatra \& Krishnan, 2017).

There is a considerable body of empirical evidence on HRIS in various research context and countries. For example, HRIS has been studied in hospitality environment in the United Kingdom (Pouransari, 2016), in Thailand's textile industry (Siengthai \& Udomphol, 2016), in Jordan's business organizations (Al-Dmour \& Love, 2015; Al-Dmour, Masa'deh, \& Obeidat, 2017) and in small and medium enterprises in Vietnam (Duc, 2016).

Anecdotal evidence suggests that information system implementation in higher education supports core business processes such as teaching and learning (Güllü et al., 2016; McLain 2017), rather than on secondary business processes such as HR processes. Research on HRIS implementation in higher education remains a void, evidenced through limited research from Aletaibi (2016), Goni et al. (2017) and Phahlane and Kekwaletswe (2017) despite the important role that the higher education sector plays in enabling transformation, supporting scarce skills, and contributing to economic growth.

The current study fills this gap by identifying HRIS implementation and influence factors, and developing a model and testing its relationships in a higher education context. This study contributes to the literature by providing insights into the implementation and influences of HRIS in higher education. Its results provide researchers and HR professionals with a model of HRIS implementation. It affirms the measures of HRIS, and offers a unique perspective of HRIS through application of the HR role model concept by identifying influences during implementation of the HR function in higher education.

\section{THEORETICAL FOUNDATIONS}

The conceptual model used in this study considers implementation and influences of HRIS (Figure 1), suggesting that successful implementation contributes to positive influences of the HR function, which in turn influences organizations positively.

HRIS implementation is built on the DeLone and McLean $(1992,2003)$ information systems success and technology trust model (McKnight, Cummings, \& Chervany, 1998). In the current study, the influences of HRIS are built on the Ulrich (1997) HR professional role.

\section{Information Systems Implementation}

Recent anecdotal evidence suggests that the DeLone and McLean model $(1992,2003)$ has been applied in cleaning logistics system research (Wei, Tang, Kao, Tseng, \& Wu, 2017), digital library success (Alzahrani, Mahmud, Ramayah, Alfarraj, \& Alalwan, 2017), e-government (Scott, DeLone, \& Golden, 2016), cloud computing (Sabri, 2016), and m-commerce (Bahaddad, 2017). DeLone and McLean (1992) propose an interactive and taxonomic model to conceptualize and operationalize information system success measures. Six dimensions comprise information systems success: information quality, 


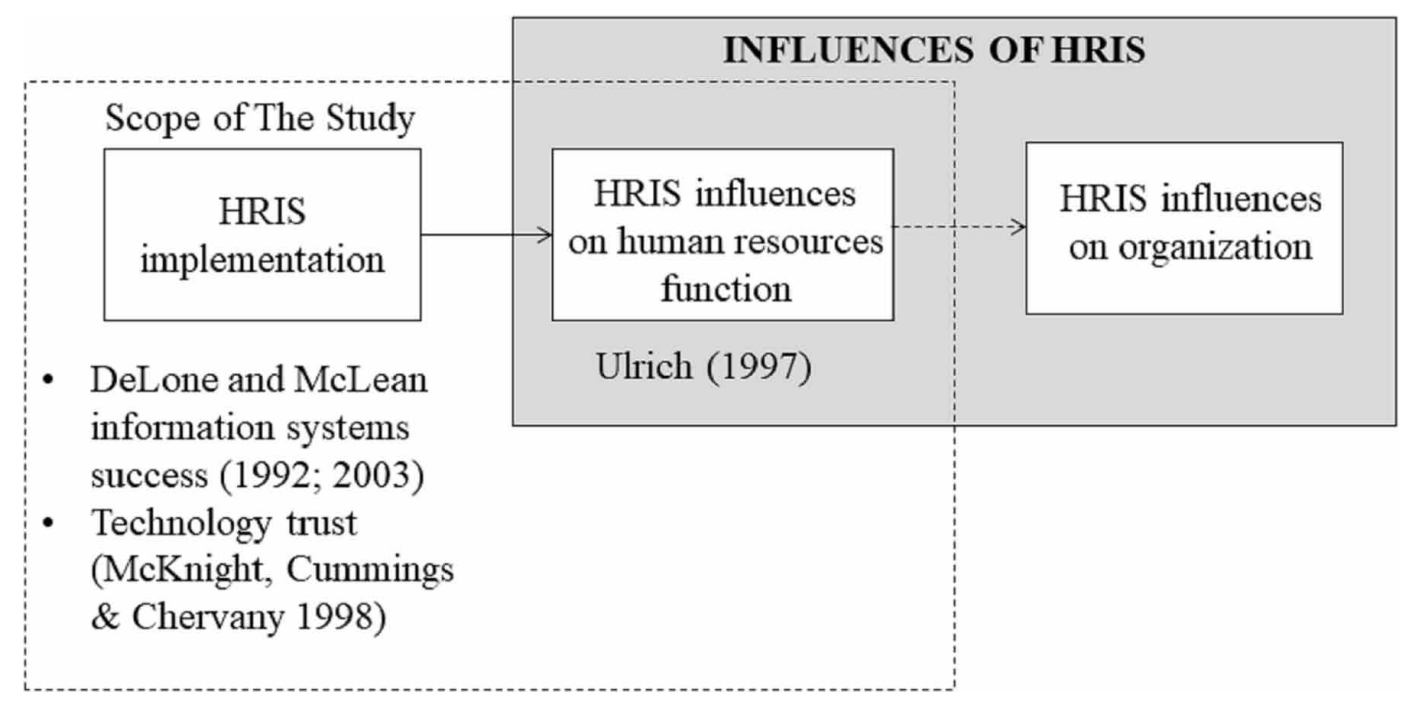

system quality, user satisfaction, use, individual impact, and organizational impact. In an update, DeLone and McLean (2003) re-specified the model to include service quality, and individual and organizational impacts were collapsed into net benefits:

- System Quality: Availability, usability, adoptability, flexibility, functionality, reliability, integration, and response time (DeLone \& McLean, 1992, 2004);

- Information Quality: Understandability, accuracy, timeliness, personalization, security, consistency, completeness, and relevance (DeLone \& McLean, 1992, 2004);

- Service Quality: Overall support delivered to employees by a system provider or information systems department (DeLone \& McLean, 2003);

- System Use: The manner and degree to which employees exploit a system's functions; a system's nature, frequency, purpose, extent, and appropriateness of use. The measure makes sense during voluntary use (DeLone \& McLean, 2003), but the current study refers to mandatory use. In view of recent research on mobile banking that acknowledges its absence (Koo, Wati, \& Chung, 2013), the current study omits the system use measure;

- User Satisfaction: Overall satisfaction of employees regarding websites, reports, and services received from an information system department (DeLone \& McLean, 2003);

- Net Benefits: The extent to which information systems influence individual, organizational, and national success; improvements to decision-making, sales increases, productivity, job creation, and economic development are notable highlights (DeLone \& McLean, 2003).

\section{Technology Trust}

The technology trust model has been used in mobile hotel booking (Ozturk, Nusair, Okumus, \& Dipendra, 2017), e-government cloud adoption (Liang, Guijie, Kangning, \& Chen, 2017), and mobile banking (Chiu, Bool, \& Chiu, 2017). Technology trust has become more pronounced with rapid technological advancements. The outcome had negative effects on employees' trust, and on their intentions to provide timely and accurate personal information. Lippert (2004) refers to technology trust, rooted in institution-based trust, as an individual's inclination to be vulnerable to technology, based on a person's expectations. Institution-based trust is concerned with technology adoption 
success based on supportive situations and structures for which technology is used; it comprises both situational normality and structural assurance.

McKnight and Chervany (2002) define situational normality as the belief that an environment is normal, customary, and proper, and therefore success of technology implementation is probable since the situation is favorable. Structural assurance considers the supportive infrastructure of technology, suggesting that an individual believes that sufficient legal, physical, and contractual support are in place to promote successful use of technology (McKnight, Carter, Thatcher, \& Clay, 2011). Trust in a specific technology refers to favorable features in terms of functionality, reliability, and helpfulness. Situational normality and structural assurance influence individual trust; believing that a situation protected by safeguards encourages an individual to believe that another person is trustworthy. An employee believes in the integrity and honesty of HRIS administrators and IT personnel if they provide assurances of advanced security procedures associated with HRIS.

\section{The Role of the Human Resources Professional (HRIS Influences on the HR Function)}

Ulrich (1997) proposes a four-role HR function model, including administration, strategy, employee championing, and change agents:

- Administrative Role: Creates an administrative infrastructure (e.g., design, redesign, and implementation of efficient recruitment, reward, promotion, and compensation), processes, and programs that deliver traditional HR services (Kuipers \& Giurge, 2016; Ulrich, 1997);

- Strategic Role: Focuses on elevating employees' productivity through job design, work organization, and work environment besides defining and implementing strategies to create business success (Kuipers \& Giurge, 2016; Ulrich, 1997);

- Employee Champion: Discovering an employee's concerns through communication (Kuipers \& Giurge, 2016; Ulrich, 1997);

- Change Agent: Managing change, easing influences of change for employees, and assuring an employee's continual commitment and motivation throughout organizational change (Kuipers \& Giurge, 2016; Ulrich, 1997).

\section{RESEARCH MODEL AND HYPOTHESES}

This study categorizes HRIS implementation into system factors, human factors, and institutionbased trust. Information and system quality comprise the system factor, and human factors comprise service quality of the help desk that supports HRIS users. Institution-based trust consists of structural assurance and situational normality. HRIS influences include users' satisfaction with HRIS and users' perceived benefits of HRIS regarding fulfilling HR functions.

\section{Perceived HRIS Benefits}

HRIS enables HR by automating HR tasks, diminishing paperwork, clarifying work processes, and dispatching useful information to top managers (Mamun \& Islam, 2016). Consequently, perceived HRIS benefits include supporting implementation of strategies, improving HR's traditional processes, initiating and adapting to change, and increasing employee commitment. This study defines HRIS benefits as an individual's evaluations of contributions derived from HRIS regarding delivering HR roles efficiently. It uses Ulrich's (1997) HR four-role model to represent perceived HRIS benefits, which accords with Caldwell (2003), who surveyed over 500 U.K. companies and investigates Ulrich's model. Voermans and van Veldhoven (2007) investigate perceived HRIS benefits, finding that HR's strategic and administrative roles and users' IT experiences influence attitudes toward e-HRM in Philips (Electronics) Netherlands. Siengthai \& Udomphol (2016) found that implementation of HRIS 
supports organizational effectiveness in Thailand. Evidence also supports that HRIS increases strategic benefits (Mamun \& Islam, 2016).

\section{User Satisfaction}

A proxy for information systems success (Zviran \& Erlich, 2003), user satisfaction was used due to its applicability and ease of use (Delone \& McLean, 2004; Zviran \& Erlich, 2003). This study refers to user satisfaction as the extent to which users believe that the HRIS is accessible to fulfil their information requirements (Ives, Olson, \& Baroudi, 1983) and the user's evaluative judgement regarding an experience with the HRIS (Doll \& Torkzadeh, 1988). Prior research has demonstrated the contributions of user satisfaction in different research context. For example, Filieri, McLeay and Tsui (2017) found that user satisfaction affects purchase intention at social commerce Websites. In another research, Tam and Oliveira (2017) found that use and user satisfaction determine individual performance in a Portuguese mobile-banking environment.

Therefore, it is hypothesized:

H1: User satisfaction correlates positively with perceived HRIS benefits.

\section{Information Quality}

In this study, information quality includes user's evaluation of the information in HRIS concerning relevance, timeliness, and accuracy (Seddon 1997). Research into information quality offers inconsistent findings. For example, McKnight et al. (2017) found the influence of information quality on trusting and distrusting beliefs in business-to-business data exchanges environment. However, while Liu et al. (2017) found a relationship between gender and information quality in a Chinese university, McGill et al. (2003) did not find a relationship between perceived information quality and intentions of using decision support systems in Australia.

Therefore, it is posited:

H2a: Information quality correlates positively with user satisfaction.

H2b: Information quality correlates positively with perceived HRIS benefits.

\section{System Quality}

This study refers to system quality as the desired characteristics of the HRIS that produces information (DeLone and McLean, 1992) and the extent to which the HRIS performs its functionalities and characteristics, or the likelihood of bugs in the system, quality of documentation, system maintainability, user interface, and ease of use (Zhang, 2010). Cappetta et al. (2015) found evidence for the role of system quality in influencing job performance among employees in an Italian retail store. More recently, system quality influences user's trust and distrust belief in business-to-business data exchanges (McKnight et al. 2017).

Therefore, it is hypothesized:

H3a: System quality correlates positively with user satisfaction.

H3b: System quality correlates positively with perceived HRIS benefits.

\section{Service Quality}

Service quality in this study refers to the degree of quality support that employees receive from the help desk. This definition spans human resource functional competence, technical proficiency, reliability, accuracy, responsiveness, assurance and empathy of support personnel (DeLone and McLean, 2003). The findings on service quality are mixed. In Pakistan, Uppal et al. (2017) found that service quality 
influences students' e-learning quality. Rahman et al. (2012), however, found that service quality affect Malaysian postgraduate students' intentions to use digital libraries negatively.

Therefore, it is postulated:

H4a: Service quality correlates positively with user satisfaction.

H4b: Service quality correlates positively with perceived HRIS benefits.

\section{Situational Normality}

This study defines situational normality (a dimension of institution-based trust) as a user's belief that the HRIS implementation is in proper order, customary, favorable, and normal to achieve success (McKnight et al., 2002). Research on situational normality has been inconsistent. Yu (2015) found a relationship between situational normality and trust beliefs among users of mobile banking in Taiwan. In Hong Kong, Chau et al. (2005), however, found that situational normality does not influence a user's trust belief in online purchase. In Ghana, Ofori et al. (2017) found situational normality to affect trust of Internet banking usage.

Therefore, it is hypothesized:

H5a: Situational normality correlates positively with user satisfaction.

H5b: Situational normality correlates positively with perceived HRIS benefits.

\section{Structural Assurance}

Structural assurance in this study is an individual's belief about the HRIS guarantees, promises, procedures, and regulations that are in place to support success (McKnight et al. 2002). Findings on structural assurance are mixed. Using a survey of students in three large U.S. universities, McKnight et al. (2002) found that structural assurance of the Web affects perceived quality and trust of a site. In Korea, Gu et al. (2009) found support for the influence of structural assurance on customers' trust of mobile banking services. However, they also found that structural assurance had no influence on the extent of website use. In Ghana, Ofori et al. (2017) found structural assurance to affect trust of Internet banking usage.

Therefore, it is hypothesized:

H6a: Structural assurance correlates positively with user satisfaction.

H6b: Structural assurance correlates positively with perceived HRIS benefits.

After consulting extant literature, the researchers categorized HRIS implementation into system factors, human factors, and institution-based trust factor. System factors comprise users' perceived information and system quality. Human factors include users' perceptions of HRIS help desk service quality, and institution-based trust consists of situational normality and structural assurance (Figure 2).

\section{METHODOLOGY}

\section{Research Context}

This study used a higher education institution in Malaysia as a research context. Malaysia is a high middle-income nation that supports critical priority for an education-reform agenda (Peeraer \& Van Petegem, 2012). The Malaysian government has given serious attention to development of talent to become a fully-developed nation by 2020 (Rahman et al., 2012). One area for development and global competitiveness is Malaysia's higher education institutions (Rosdi \& Harris, 2011). The 


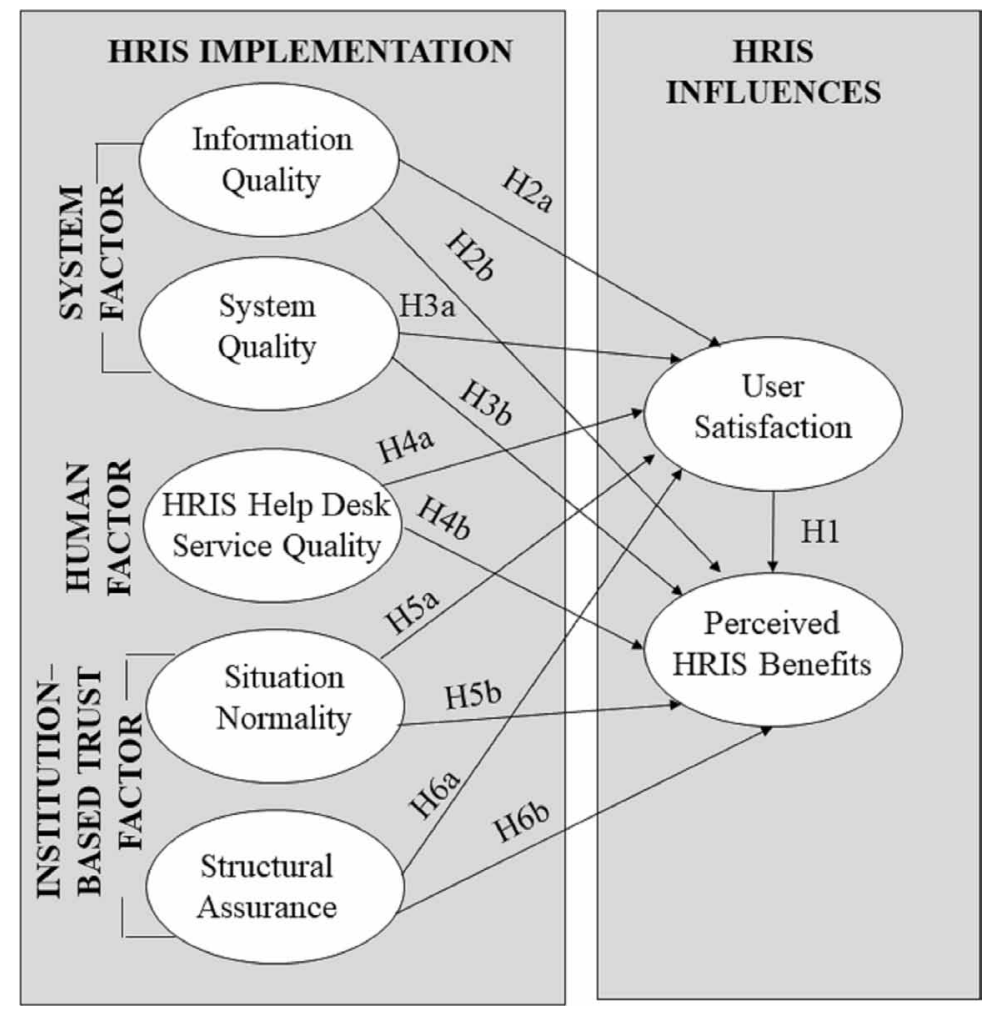

government has urged higher education institutions to create critical environments of knowledge through skilled employees who support a knowledge-based economy (Sohail \& Daud, 2009). A quality, knowledgeable workforce is crucial for Malaysia's higher education to become an educational hub, which is especially relevant to faculty members who educate students, conduct research, and participate in student development (Rosdi \& Harris, 2011). Higher education institutions that apply these strategic initiatives may implement tools to monitor progress. While modelling the practices of corporations, higher education public institutions might use performance management systems as monitoring tools.

\section{Data Collection}

A questionnaire was used to collect data. This study used employee performance management systems as a comprehensive HRIS context at a public higher education institution in Malaysia. The HRIS was developed and implemented from scratch, and was fully commissioned in 2012 to monitor fulfilment of the institution's strategic goals. No other institution in the higher education industry in the country used a similar system at the time of data collection. The system records employee profile data, and stores annual performance information at the institution. HRIS data are analyzed periodically to monitor the institution's progress of meeting its strategic goals.

\section{Population and Sample}

The population was defined as HRIS users (i.e., academic or administrative staff) at the institution. Both academic and administrative staff members use similar HRIS to access their profiles and performance records. The estimated population was 6,000 . Convenience sampling was used to gather data, and 
responses were voluntary. Two hundred questionnaires were distributed, and 103 were returned, with a sample drawn from administrative offices, schools, and faculty members at the institution.

\section{Instrument}

A questionnaire that comprised eight sections was developed based on extant research. Section A included demographics (i.e., age, gender, academic qualifications, and overall work experience). Section B measured information quality (i.e., information format, usefulness, clarity, and quality), and Section C measured system quality (i.e., ease of use, features, usability, and responsiveness). Section D included service quality items to measure the responsiveness, empathy, and competencies of the IT help desk. Sections E and F measured situational normality and structural assurance, and Section $G$ included user satisfaction items. Section $\mathrm{H}$ measured perceived HRIS benefits. Table 1 shows the sources of measures that appeared on the questionnaire.

Table 1. Measures and sources of measures

\begin{tabular}{|l|l|}
\hline \multicolumn{1}{|c|}{ Measure } & \multicolumn{1}{c|}{ Source } \\
\hline Information quality & Shibly (2011); Chen \& Cheng (2009) \\
\hline System quality & Shibly (2011); Chen (2010); Hartono et al. (2007) \\
\hline Service quality & Lin (2010) \\
\hline Situational normality & McKnight et al. (2011) \\
\hline Structural assurance & McKnight et al. (2002) \\
\hline User satisfaction & Shibly (2011); Lin (2010) \\
\hline Perceived HRIS benefits & Ulrich (1997) \\
\hline
\end{tabular}

The researchers conducted a pilot study to test the reliability of an initial questionnaire, which used a Likert-type scale for items that measured individual perceptions $(5=$ strongly agree, $1=$ strongly disagree, and $3=$ a neutral response). Forty-two academic and administrative (non-academic) staff members selected from multiple faculties and schools were the pilot study's participants. Results demonstrated that most participants selected the middle point on the scale, and therefore the scale was revised to have 6 points. The scale on the final questionnaire ranged from 1 (strongly disagree) to 6 (strongly agree). A 6-point scale was used to limit respondents' option of avoiding an issue in some contexts (Weijters et al., 2010). The scale appears in the Appendix.

\section{Data Analysis}

Statistical software was used to generate descriptive statistics for a profile of respondents. An independent samples t-test was calculated to determine whether there was a difference between the academic and administrative groups, with findings suggesting a difference for perceived benefits, user satisfaction, situational normality, system quality, and information quality $(\mathrm{p}<0.05)$. For those factors, administrators reported higher evaluations than academic staff members did. Subsequent analyses used partial least squares and SmartPLS (Ringle, Wende, $\&$ Will, 2005) to analyze paths and relationships among constructs. Since this study examines a Malaysian higher education institution, responses from the academic and administrative staff members were aggregated. 


\section{RESULTS}

\section{Profile of Respondents}

Table 2 shows respondents' profiles. Most respondents were above thirty years old. Women comprised a larger portion of respondents (55.3\%), and academic participants were the majority (67\%). Most respondents held master's and doctoral degrees, and more than $50 \%$ had greater than 16 years of work experience.

Table 2. Profile of respondents

\begin{tabular}{|c|c|c|c|}
\hline Characteristics & Item & Frequency & Percentage \\
\hline \multirow{4}{*}{ Age } & $20-29$ & 12 & 11.7 \\
\hline & $30-39$ & 32 & 31.1 \\
\hline & $40-49$ & 21 & 20.4 \\
\hline & $>49$ & 38 & 36.9 \\
\hline \multirow{2}{*}{ Gender } & Female & 57 & 55.3 \\
\hline & Male & 46 & 44.7 \\
\hline \multirow{2}{*}{ Academic } & Academic & 69 & 67 \\
\hline & Non-academic & 34 & 33 \\
\hline \multirow{6}{*}{ Academic qualification } & Bachelor's & 10 & 9.7 \\
\hline & Certificate & 10 & 9.7 \\
\hline & Diploma & 12 & 11.7 \\
\hline & Master's & 25 & 24.3 \\
\hline & Doctoral & 45 & 43.7 \\
\hline & Post-doc & 1 & 1 \\
\hline \multirow{6}{*}{ Work experience } & $<1$ & 1 & 1 \\
\hline & $1-5$ & 17 & 16.5 \\
\hline & $6-10$ & 19 & 18.4 \\
\hline & $11-15$ & 11 & 10.7 \\
\hline & $16-20$ & 11 & 10.7 \\
\hline & $>20$ & 44 & 42.7 \\
\hline
\end{tabular}

\section{Partial Least Squares Analysis}

Data were analyzed to assess convergent validity, which is acceptable if loadings of measures to respective constructs are at least 0.60 (Bagozzi \& Yi, 1988; Kline, 2005), composite reliabilities (CR) of all constructs are above 0.6 (Bagozzi \& Yi, 1988; Kline, 2005), and average variances extracted (AVE) are above 0.5 (Fornell \& Larcker, 1981). Table 3 shows the loadings, composite reliabilities, and average variances extracted. All items met the cut-off loadings, and therefore no items were removed. Intervariable correlations (Table 4) were then examined, with the square roots of the AVEs greater than correlations, suggesting that constructs related more closely to their own measures and supporting discriminant validity (Kline, 2005). To test the hypothesized relationships, path estimates and t-statistics were then calculated (Table 5 and Figure 3). 
International Journal of Asian Business and Information Management

Volume $11 \cdot$ Issue $3 \cdot$ July-September 2020

Table 3. Loadings, composite reliability, and average variance extracted

\begin{tabular}{|c|c|c|c|c|}
\hline Construct/Item Code & Item & Loading & CR & AVE \\
\hline \multirow{16}{*}{$\begin{array}{l}\text { Perceived HRIS benefits } \\
\text { (PB) }\end{array}$} & PB1 & 0.85 & \multirow{16}{*}{0.979} & \multirow{16}{*}{0.745} \\
\hline & PB2 & 0.88 & & \\
\hline & PB3 & 0.893 & & \\
\hline & PB4 & 0.862 & & \\
\hline & PB5 & 0.865 & & \\
\hline & PB6 & 0.822 & & \\
\hline & PB7 & 0.839 & & \\
\hline & PB8 & 0.82 & & \\
\hline & PB9 & 0.859 & & \\
\hline & PB10 & 0.89 & & \\
\hline & PB11 & 0.858 & & \\
\hline & PB12 & 0.893 & & \\
\hline & PB13 & 0.88 & & \\
\hline & PB14 & 0.863 & & \\
\hline & PB15 & 0.882 & & \\
\hline & PB16 & 0.854 & & \\
\hline \multirow{4}{*}{ User satisfaction (US) } & US1 & 0.941 & \multirow{4}{*}{0.976} & \multirow{4}{*}{0.911} \\
\hline & US2 & 0.956 & & \\
\hline & US3 & 0.97 & & \\
\hline & US4 & 0.95 & & \\
\hline \multirow{4}{*}{ Information quality (IQ) } & IQ1 & 0.805 & \multirow{4}{*}{0.907} & \multirow{4}{*}{0.709} \\
\hline & IQ2 & 0.791 & & \\
\hline & IQ3 & 0.905 & & \\
\hline & IQ4 & 0.863 & & \\
\hline \multirow{4}{*}{ System quality (SQ) } & SQ1 & 0.864 & \multirow{4}{*}{0.911} & \multirow{4}{*}{0.72} \\
\hline & SQ2 & 0.852 & & \\
\hline & SQ3 & 0.831 & & \\
\hline & SQ4 & 0.847 & & \\
\hline \multirow{4}{*}{ Service quality (SR) } & SR1 & 0.745 & \multirow{4}{*}{0.901} & \multirow{4}{*}{0.696} \\
\hline & SR2 & 0.853 & & \\
\hline & SR3 & 0.831 & & \\
\hline & SR4 & 0.90 & & \\
\hline \multirow{4}{*}{ Situation normality (SN) } & SN1 & 0.918 & \multirow{4}{*}{0.962} & \multirow{4}{*}{0.863} \\
\hline & $\mathrm{SN} 2$ & 0.943 & & \\
\hline & SN3 & 0.925 & & \\
\hline & SN4 & 0.93 & & \\
\hline \multirow{4}{*}{ Structural assurance (SA) } & SA1 & 0.918 & \multirow{4}{*}{0.964} & \multirow{4}{*}{0.871} \\
\hline & SA2 & 0.932 & & \\
\hline & SA3 & 0.943 & & \\
\hline & SA4 & 0.941 & & \\
\hline
\end{tabular}


Table 4. Inter-variable correlations

\begin{tabular}{|l|l|l|l|l|l|l|l|}
\hline & \multicolumn{1}{|c|}{$\mathbf{1}$} & \multicolumn{1}{|c|}{$\mathbf{2}$} & \multicolumn{1}{|c|}{$\mathbf{3}$} & \multicolumn{1}{c|}{$\mathbf{4}$} & \multicolumn{1}{|c|}{$\mathbf{5}$} & \multicolumn{1}{c|}{} & $\mathbf{7}$ \\
\hline 1. PB & $\mathbf{0 . 8 6 3}$ & & & & & & \\
\hline 2. US & 0.774 & $\mathbf{0 . 9 5 4}$ & & & & & \\
\hline 3. IQ & 0.601 & 0.643 & $\mathbf{0 . 8 4 2}$ & & & & \\
\hline 4. SQ & 0.686 & 0.739 & 0.64 & $\mathbf{0 . 8 4 9}$ & & & \\
\hline 5. SR & 0.606 & 0.647 & 0.55 & 0.606 & $\mathbf{0 . 8 3 4}$ & & \\
\hline 6. SN & 0.796 & 0.854 & 0.659 & 0.81 & 0.737 & $\mathbf{0 . 9 2 9}$ & \\
\hline 7. SA & 0.609 & 0.633 & 0.431 & 0.635 & 0.608 & 0.647 & $\mathbf{0 . 9 3 3}$ \\
\hline
\end{tabular}

Table 5. Summary of path estimates and support for hypotheses

\begin{tabular}{|l|l|l|l|l|l|}
\hline \multicolumn{1}{|c|}{$\mathbf{H}$} & \multicolumn{1}{|c|}{ Path } & \multicolumn{1}{c|}{ Beta } & \multicolumn{1}{c|}{ SD } & \multicolumn{1}{c|}{ t-Stat } & \multicolumn{1}{c|}{ Support } \\
\hline 1 & User satisfaction $\rightarrow$ Perceived benefit & 0.282 & 0.111 & 2.545 & Yes \\
\hline $2 \mathrm{a}$ & Information quality $\rightarrow$ User satisfaction & 0.133 & 0.067 & 1.991 & Yes \\
\hline $2 \mathrm{~b}$ & Information quality $\rightarrow$ Perceived benefit & 0.094 & 0.092 & 1.018 & No \\
\hline $3 \mathrm{a}$ & System quality $\rightarrow$ User satisfaction & 0.055 & 0.057 & 0.09 & No \\
\hline $3 \mathrm{~b}$ & System quality $\rightarrow$ Perceived benefit & 0.012 & 0.014 & 0.135 & No \\
\hline $4 \mathrm{a}$ & Service quality $\rightarrow$ User satisfaction & -0.019 & -0.014 & 0.237 & No \\
\hline $4 \mathrm{~b}$ & Service quality $\rightarrow$ Perceived benefit & -0.018 & -0.006 & 0.167 & No \\
\hline $5 \mathrm{a}$ & Situational normality $\rightarrow$ User satisfaction & 0.651 & 0.171 & 6.568 & Yes \\
\hline $5 \mathrm{~b}$ & Situational normality $\rightarrow$ Perceived benefit & 0.417 & 0.099 & 2.436 & Yes \\
\hline $6 \mathrm{a}$ & Structural assurance $\rightarrow$ User satisfaction & 0.132 & 0.079 & 1.658 & Yes \\
\hline $6 \mathrm{~b}$ & Structural assurance $\rightarrow$ Perceived benefit & 0.124 & 0.09 & 1.372 & No \\
\hline
\end{tabular}

\section{Support for Hypotheses}

User satisfaction correlated positively with perceived HRIS benefits $(\beta=0.282$; $t$-stat $=2.545)$, supporting $\mathrm{H} 1$ and findings from Tam and Oliveira (2017). H2a suggests a positive relationship between information quality and user satisfaction, with support found for the relationship $(\beta=0.133$; $\mathrm{t}$-stat=1.991). H2b suggests a positive relationship between information quality and perceived HRIS benefits, but no evidence was found for the relationship $(\beta=0.094$; t-stat=1.018). H3a suggests a positive relationship between system quality and user satisfaction, but the hypothesis was not supported $(\beta=0.055$; $\mathrm{t}-\mathrm{stat}=0.09)$. H3b suggests a positive correlation between system quality and perceived HRIS benefits, but no support was found for the relationship $(\beta=0.012$; $t$-stat $=0.135)$, which is inconsistent with McKnight et al. (2017). H4a suggests a positive relationship between service quality and user satisfaction, but no support was found $(\beta=-0.019$; $t$-stat $=0.237)$. H4b suggests a positive relationship between service quality and perceived HRIS benefits, but the hypothesis was not supported $(\beta=-0.018$; $t$-stat=0.167), which is inconsistent with Uppal et al. (2017). H5a suggests a positive relationship between situation normality and user satisfaction, with support found $(\beta=0.651$; $\mathrm{t}$-stat=6.568). H5b suggests a positive relationship between situation normality and perceived HRIS benefits, and evidence supported the relationship $(\beta=0.417$; $t$-stat $=2.436)$, which is consistent with Ofori et al. (2017). H6a suggests a positive relationship between structural assurance and user 


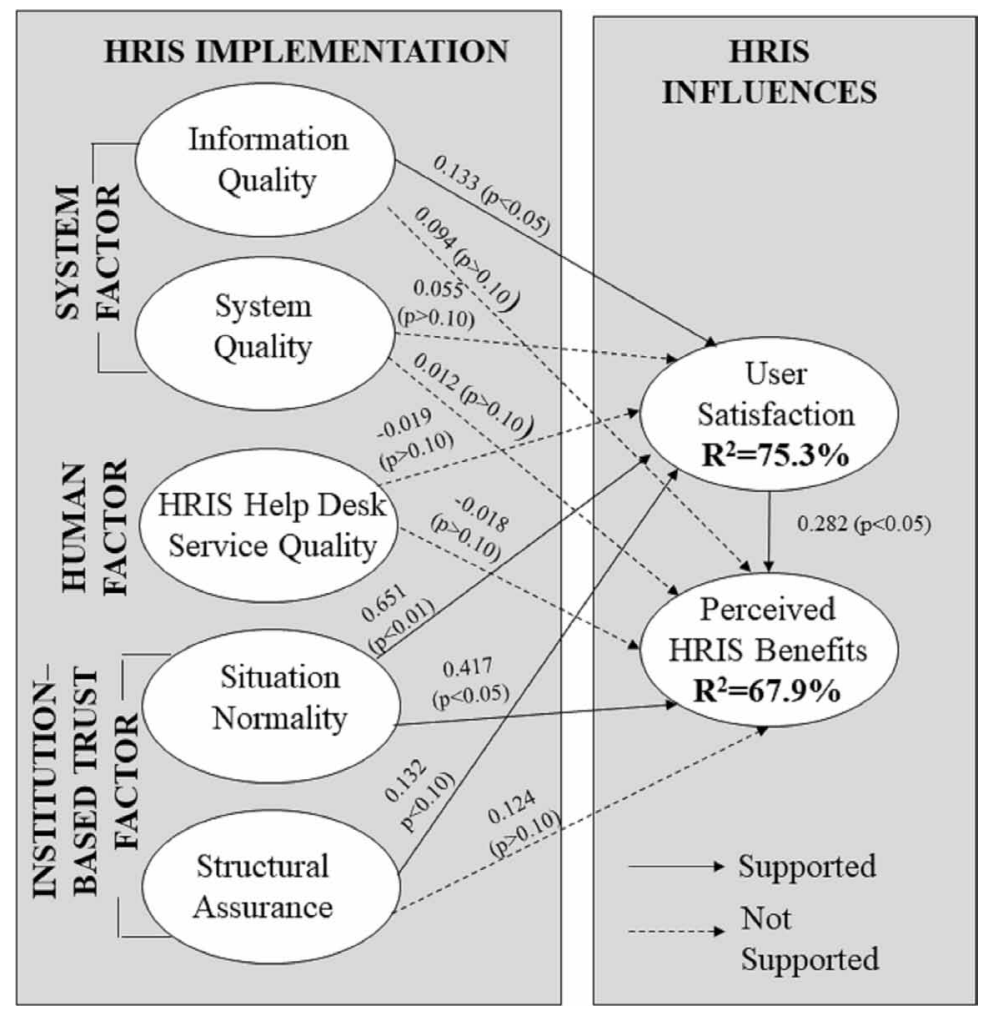

satisfaction, with support found $(\beta=0.132$; $t$-stat=1.658), which accords with Ofori et al. (2017). H6b suggests a positive relationship between structural assurance and perceived HRIS benefits, but no support was found for the relationship ( $\beta=0.124$; $\mathrm{t}$-stat=1.372). A total of $75.3 \%$ of variation in user satisfaction was explained by information quality, situation normality, and structural assurance of institution-based trust. This finding suggests that individual perceived quality of information in HRIS, situation normality, and structural assurance influence satisfaction with HRIS use. A total of $67.9 \%$ of the variation in HRIS benefits was explained by user satisfaction and situation normality.

\section{DISCUSSION AND CONCLUSION}

\section{Summary of Findings}

Advancement in technology encouraged development and widespread use of computer based HRIS. HRIS is an enabler of greater productivity of the HR function and organizations. For decades, measuring IT benefits was an interest of both practitioners and researchers, but despite much research on the issue, HRIS implementation in higher education was rare, motivating this study, which conceptualizes HRIS implementation as system quality, information quality, service quality of the help desk, structural assurance of trust, and situation normality of trust. This study categorizes HRIS implementation into system factors (i.e., information quality and system quality), human factors (i.e., HRIS help desk service quality), and institution-based trust factors (i.e., situation normality and structural assurance). Influences are conceptualized as user satisfaction with HRIS and perceived benefits of HRIS. Perceived benefits are conceptualized as the capability of an information system to fulfill the HR role models of administration, strategy, employee championing, and change agents. 
Users were selected from academicians and non-academicians at a Malaysian higher education institution. User satisfaction with HRIS was an essential factor of perceived HRIS benefits. Users satisfied with HRIS reported that HRIS enables change in an educational institution, aligns HR and organizational strategies, improves HR management, and enhances productivity. This study supports the role of system factors in information quality on user satisfaction; users are more satisfied with HRIS when it is perceived as high quality, it meets expectations, and interactions with the HRIS are satisfying. Users who do not regard HRIS as high quality do not feel satisfied with their interactions with HRIS. Institution-based trust (i.e., situation normality and structural assurance) predicts user satisfaction; users are more satisfied with HRIS when they are comfortable working with it, feel good about how things go when they use it, feel confident that the right things will happen with use of it, and think that things will be fine when they use it. Users are more satisfied with use of HRIS when they receive assurance that it has adequate safeguards to keep their performance data private and that confidential data are safe. For users to perceive that it provides benefits, HRIS must ensure that users are satisfied with the system and they perceive its implementation accords with proper order and is favorable to the users. Users dissatisfied with HRIS do not perceive its benefits. This study did not support an influence of human factors of HRIS implementation on its outcomes, suggesting that human factors might include other elements not captured in the study. However, findings answer the research question and fulfill the objective of developing a model and testing relationships that explain the implementation and influences of HRIS.

\section{Contributions to Theory and Practice}

From a theoretical perspective, this study identifies user satisfaction with HRIS and perceived benefits as HRIS influences. Research corroborates the capability of the four-role model HR function when explaining HRIS perceived benefits in a higher education context. This study develops a theoretical model that explains users' satisfaction with HRIS and perceived HRIS benefits in higher education. It supports the role of system and institution-based trust factor as HRIS implementation factors when explaining HRIS influences. Contrary to extant findings, only information quality, situational normality, and structural assurance predicted user satisfaction with HRIS, and only user satisfaction with HRIS and situation normality correlated with perceived benefits.

From a practical perspective, this study corroborates the role of HRIS in the HR function, especially regarding discharging administrative roles, strategic roles, employee championing, and change agents. This study provides a means for executives to measure information systems and perceived benefits from an HR perspective. Since the measures demonstrated internal consistency, they can be adapted to other organizational settings, including large corporate environments. For the HR function to discharge its role, HRIS must allow academic and non-academic employees to self-serve. The role of institution-based trust cannot be emphasized. HRIS developers should concurrently provide assurances of system factors by making quality information available to users and ensuring that users' private data remain safe. By assuring continued productivity with HRIS implementation while equally managing employees' development and performance, policy-makers should ensure that procedures are compatible with HRIS use.

\section{Limitations and Future Research}

The sample size of 103 participants was small. Convenience sampling was used, and hence findings cannot be generalized to the population (Sekaran, 2006). The study was also conducted in a single Malaysian education institution at one point in time. These limitations suggest opportunities for future investigations. Future research should apply, adapt, and test the instrument and model for its applicability in a large corporate environment. Research should also use larger samples across various higher education institutions. An examination using a larger number of participants might identify disparities in relationships between academic and administrative participants. Longitudinal designs that draw on balanced proportions of academic and administrative participants might suggest differences across samples. Qualitative interviews should also be used to gain insights into differences between academic and administrative participants. 


\section{REFERENCES}

Al-Dmour, R. H., \& Love, S. (2015). Determinants of the implementation of HRIS applications in business organisations in Jordan. International Journal of Human Resources Development and Management, 15(1), 69-96. doi:10.1504/IJHRDM.2015.069974

Al-Dmour, R. H., Masa'deh, R., \& Bader Yousef Obeidat, B. Y. (2017). Factors influencing the adoption and implementation of HRIS applications: Are they similar? International Journal of Business Innovation and Research, 14(2), 139-167. doi:10.1504/IJBIR.2017.086276

Aletaibi, R. G. (2016). An analysis of the adoption and use of HRIS in the public universities in Saudi Arabia. Unpublished doctoral dissertation, Coventry University, UK.

Alzahrani, A. I., Mahmud, I., Ramayah, T., Alfarraj, O., \& Alalwan, N. (2017). Modelling digital library success using the DeLone and McLean information system success model. Journal of Librarianship and Information Science. doi:10.1177/0961000617726123

Bagozzi, R. P., \& Yi, Y. (1988). On the evaluation of structural equation models. Journal of the Academy of Marketing Science, 16(1), 74-94. doi:10.1007/BF02723327

Bahaddad, A. A. (2017). Evaluating m-commerce systems success: Measurement and validation of the DeLone and McLean model of IS success in Arabic society (GCC case study). Journal of Business Theory and Practice, 5(3), 156-193. doi:10.22158/jbtp.v5n3p156

Caldwell, R. (2003). The changing roles of personnel managers: Old ambiguities, new uncertainties. Journal of Management Studies, 40(4), 983-1004. doi:10.1111/1467-6486.00367

Cappetta, R., Maruping, L., Madden, J., \& Magni, M. (2015, December). Employee self-service technology and performance: The role of learning transfer and involvement. Proceedings of the thirty-sixth International Conference on Information Systems, Fort Worth, TX. Academic Press.

Chau, P., Hu, P., Lee, B., \& Au, A. (2005, July). Understanding consumer trust in online purchase processes: An experimental investigation. Proceedings of the PACIS 2005, Bangkok, Thailand. Academic Press.

Chen, C.-W. D., \& Cheng, C.-Y. J. (2009). Understanding consumer intention in online shopping: A respecification and validation of the DeLone and McLean model. Behaviour \& Information Technology, 28(4), 335-345. doi:10.1080/01449290701850111

Chiu, J. L., Bool, N. C., \& Chiu, C. L. (2017). Challenges and factors influencing initial trust and behavioral intention to use mobile banking services in the Philippines. Asia Pacific Journal of Innovation and Entrepreneurship, 11(2), 246-278. doi:10.1108/APJIE-08-2017-029

Chowdhury, J., Bandhyapadhya, P., \& Hazra, G. (2012). Integration of human resource information system to DSS, CMS and other applications to increase productivity. International Journal of Computers and Technology, $3(1), 55-59$.

DeLone, W. H., \& McLean, E. R. (1992). Information systems success: The quest for the dependent variable. Information Systems Research, 3(1), 60-95. doi:10.1287/isre.3.1.60

DeLone, W. H., \& McLean, E. R. (2003). The DeLone and McLean model of information system success: A tenyear update. Journal of Management Information Systems, 19(4), 9-30. doi:10.1080/07421222.2003.11045748

DeLone, W. H., \& McLean, E. R. (2004). Measuring e-commerce success: Applying the DeLone \& McLean information systems success model. International Journal of Electronic Commerce, 9(1), 31-47. doi:10.1080 /10864415.2004.11044317

Doll, W. J., \& Torkzadeh, G. (1988). The measurement of end-user computing satisfaction. Management Information Systems Quarterly, 12(2), 259-274. doi:10.2307/248851

Duc, N. N. (2016). Exploring SMEs perception and trust toward HRIS for a sustainable HRM performance: Case study of SMEs in Vietnam. In C. Campbell \& J. J. Ma (Eds.), Looking forward, looking back: Drawing on the past to shape the future of marketing (pp. 171-174). New York, NY: Springer International. doi:10.1007/9783-319-24184-5_44 
Filieri, R., McLeay, F., \& Tsui, B. (2017). Antecedents of travellers' satisfaction and purchase intention from social commerce Websites. In R. Schegg \& B. Stangl (Eds.), Information and Communication Technologies in Tourism 2017. Springer International Publishing. doi:10.1007/978-3-319-51168-9_37

Fornell, C. R., \& Larcker, D. F. (1981). Evaluating structural equation models with unobserved variables and measurement error. JMR, Journal of Marketing Research, 18(1), 39-50. doi:10.1177/002224378101800104

Goni, F. A., Chofreh, A. G., Mukhtar, M., Sahran, S., Abdul Shukor, S., \& Klemeš, J. J. (2017). Strategic alignment between sustainability and information systems: A case analysis in Malaysian public higher education institutions. Journal of Cleaner Production, 168, 263-270. doi:10.1016/j.jclepro.2017.09.021

Gu, J.-C., Lee, S.-C., \& Suh, Y.-H. (2009). Determinants of behavioral intention to mobile banking. Expert Systems with Applications, 36(9), 11605-11616. doi:10.1016/j.eswa.2009.03.024

Gulla, J. (2012). Seven reasons IT projects fail. IBM system Mag. Retrieved from http://www.ibmsystemsmag. com/power/Systems-Management/Workload-Management/project_pitfalls/

Güllü, F., Kuusik, R., Shogenov, K., Laanpere, M., Oysal, Y., Ömer Faruk Sözcü, O. M., \& Zekeriya Parlak, Z. (2016). An analysis and comparison of adoption of e-learning systems in higher education by lecturers at largest universities in Estonia and Turkey. Baltic Journal Modern Computing, 4(3), 428-440.

Hartono, E., Santhanam, R., \& Holsapple, C. W. (2007). Factors that contribute to management support system success: An analysis of field studies. Decision Support Systems, 43(1), 256-268. doi:10.1016/j.dss.2006.09.012

Iijima, T. (2015). Key points of failure for IT project business cases. Journal of Corporate Accounting \& Finance, 26(4), 57-63. doi:10.1002/jcaf.22051

Ives, B., Olson, M. H., \& Baroudi, J. J. (1983). The measurement of user information satisfaction. Communications of the ACM, 26(10), 785-793. doi:10.1145/358413.358430

Kassim, N. M., Ramayah, T., \& Kurnia, S. (2012). Antecedents and outcomes of human resource information system (HRIS) use. International Journal of Productivity and Performance Management, 61(6), 603-623. doi:10.1108/17410401211249184

Khan, H., Hussainy, S. K., Kamran, K., \& Khan, A. (2017). The applications, advantages and challenges in the implementation of HRIS in Pakistani perspective. VINE Journal of Information and Knowledge Management Systems, 47(1), 137-150. doi:10.1108/VJIKMS-01-2016-0005

Kline, R. B. (2005). Principles and practice of structural equation modelling. New York, NY: Guilford Press.

Koo, C., Wati, Y., \& Chung, N. (2013). A study of mobile and Internet banking service: Applying for IS success model. Asia Pacific Journal of Information Systems, 23(1), 65-86.

Kovach, K. A., Hughes, A. A., Fagan, P., \& Maggitti, P. G. (2002). Administrative and strategic advantages of HRIS. Employment Relations Today, 29(2), 43-48. doi:10.1002/ert.10039

Kramar, R. (2012). Trends in Australian human resource management: What next? Asia Pacific Journal of Human Resources, 50(2), 133-150. doi:10.1111/j.1744-7941.2011.00009.x

Kuipers, B. S., \& Giurge, L. M. (2016). Does alignment matter? The performance implications of HR roles connected to organizational strategy. International Journal of Human Resource Management, 28(22), 3179-3201. doi:10.1080/09585192.2016.1155162

Law, C. C., \& Ngai, E. W. (2007). ERP systems adoption: An exploratory study of the organizational factors and impacts of ERP success. Information \& Management, 44(4), 418-432. doi:10.1016/j.im.2007.03.004

Liang, Y., Guijie, Q., Kangning, W., \& Chen, J. (2017). Exploring the determinant and influence mechanism of e-Government cloud adoption in government agencies in China. Government Information Quarterly, 34(3), 481-495. doi:10.1016/j.giq.2017.06.002

Lin, H.-F. (2010). An investigation into the effects of IS quality and top management support on ERP system usage. Total Quality Management, 21(3), 335-349. doi:10.1080/14783360903561761 
Lippert, S. K. (2004). The effect of trust on personal Web usage in the workplace. In M. Anandarajan \& C. A. Simmers (Eds.), Personal web usage in the workplace: A guide to effective human resources management (pp. 80-110). Hershey, PA: IGI Global. doi:10.4018/978-1-59140-148-3.ch005

Liu, Y., Li, Y., Zhang, H., \& Huang, W. W. (2017). Gender differences in information quality of virtual communities: A study from an expectation-perception perspective. Personality and Individual Differences, 104, 224-229. doi:10.1016/j.paid.2016.08.011

Mahapatra, M., \& Krishnan, S. (July 2017). Adoption of Open Source ERP in Small and Medium-sized Enterprises. Proceedings of the PACIS 2017, Langkawi, Malaysia. Academic Press. Retrieved from http://aisel. aisnet.org/pacis2017/171

Mamun, M. A. A., \& Islam, M. S. (2016). Perception of Management on Outcomes of Human Resource Information System (HRIS). International Journal of Business and Social Research, 6(2), 29-37. doi:10.18533/ ijbsr.v6i2.837

Mayfield, M., Mayfield, J., \& Lunce, S. (2003). Human resource information systems: A review and model development. Advances in Competitiveness Research, 11(1), 139-151.

McGill, T., Hobbs, V., \& Klobas, J. (2003). User developed applications and information systems success: A test of DeLone and McLean's model. Information Resources Management Journal, 16(1), 24-45. doi:10.4018/ irmj.2003010103

McKnight, D. H., Carter, M., Thatcher, J. B., \& Clay, P. F. (2011). Trust in a specific technology: An investigation of its components and measures. ACM Transactions on Management Information Systems, 2(2), 1-15. doi:10.1145/1985347.1985353

McKnight, D. H., \& Chervany, N. L. (2002). What trust means in e-commerce customer relationships: An interdisciplinary conceptual typology. International Journal of Electronic Commerce, 6(2), 35-60. doi:10.108 $0 / 10864415.2001 .11044235$

McKnight, D. H., Choudhury, V., \& Kacmar, C. (2002). Developing and validating trust measures for e-commerce: An integrative typology. Information Systems Research, 13(3), 334-359. doi:10.1287/isre.13.3.334.81

McKnight, D. H., Cummings, L. L., \& Chervany, N. L. (1998). Initial trust formation in new organizational relationships. Academy of Management Review, 23(3), 473-490. doi:10.5465/amr.1998.926622

McKnight, D. H., Lankton, N. K., Andreas, N., Nicolaou, A., \& Price, J. (2017). Distinguishing the effects of B2B information quality, system quality, and service outcome quality on trust and distrust. The Journal of Strategic Information Systems, 26(2), 118-141. doi:10.1016/j.jsis.2017.01.001

McLain, T. R. (2017). Learning management systems adoption conundrums-Technological and pedagogical dilemmas that arise for higher education. Journal of Education and Training, 4(2), 124-130. doi:10.5296/jet. v4i2.11646

Nattapol, N., Peter, R., \& Laddawan, K. (2010). An investigation of the determinants of knowledge management systems success in banking industry. World Academy of Science, Engineering and Technology, 71, 588-595.

Ngai, E. W. T., \& Wat, F. K. T. (2006). Human resource information systems: A review and empirical analysis. Personnel Review, 35(3), 351-371. doi:10.1108/00483480610656702

Nyame, P. K. O., \& Boateng, R. (2015, April). The adoption and use of human resource information system (HRIS) in Ghana. Proceedings of the 17th International Conference on Enterprise Information Systems (ICEIS), Barcelona (Vol. 3, pp. 130-138). Academic Press. doi:10.5220/0005458101300138

Ofori, K. S., Henry Boateng, H., Okoe, A. F., \& Gvozdanovic, I. (2017). Examining customers' continuance intentions towards internet banking usage. Marketing Intelligence \& Planning, 35(6), 756-773. doi:10.1108/ MIP-11-2016-0214

Ozturk, A. B., Nusair, K., Okumus, F., \& Dipendra, S. (2017). Understanding mobile hotel booking loyalty: An integration of privacy calculus theory and trust-risk framework. Information Systems Frontiers, 19(4), $753-767$. doi:10.1007/s10796-017-9736-4 
Peeraer, J., \& Van Petegem, P. (2012). Measuring integration of information and communication technology in education: An item response modeling approach. Computers \& Education, 58(4), 1247-1259. doi:10.1016/j. compedu.2011.12.015

Phahlane, M. M., \& Kekwaletswe, R. M. (2017, March). A conceptual research framework for human resource information systems adoption and use in universities. Proceedings of the 2017 Conference on Information Communications Technology and Society, South Africa. Academic Press. doi:10.1109/ICTAS.2017.7920654

Pouransari, S. (2016). The effect of human resource information systems (HRIS) on staff retention: a study of recruitment and selection in a UK based hospitality organization. Unpublished doctoral dissertation, Brunel University, UK.

Rahman, A. L. A., Jamaludin, A., \& Mahmud, Z. (2012). Intention to use digital library based on modified UTAUT model: Perspectives of Malaysian postgraduate students. World Academy of Science, Engineering and Technology, 75, 116-122.

Razali, M. Z., \& Vrontis, D. (2010). The reactions of employees toward the implementation of human resources information systems (HRIS) as a planned change program: A case study in Malaysia. Journal of Transnational Management, 15(3), 229-245. doi:10.1080/15475778.2010.504497

Ringle, C. M., Wende, S., \& Will, S. (2005). SmartPLS 2.0 (M3) beta. Retrieved from http://www.smartpls.de

Rosdi, I. S., \& Harris, H. (2011, March). Human resource management practices and organisational commitment: The case of academics in a Malaysian higher education institution. Paper presented at the International Conference on Business and Economic Research, Kedah, Malaysia. Academic Press.

Sabri, O. (2016). Applying the updated Delone and Mclean is success model for enterprise cloud computing readiness. International Journal of Cloud Applications and Computing, 6(2), 49-54. doi:10.4018/ IJCAC.2016040105

Scott, M., DeLone, W., \& Golden, W. (2016). Measuring eGovernment success: A public value approach. European Journal of Information Systems, 25(3), 187-208. doi:10.1057/ejis.2015.11

Seddon, P. B. (1997). A respecification and extension of the DeLone and McLean model of IS success. Information Systems Research, 8(3), 240-253. doi:10.1287/isre.8.3.240

Sekaran, U. (2006). Research methods for business: A skill building approach. New York: John Wiley \& Sons.

Shibly, H. (2011). Human resources information systems success assessment: An integrative model. Australian Journal of Basic and Applied Sciences, 5(5), 157-169.

Siengthai, S., \& Udomphol, A. (2016). The impact of human resource information system (HRIS) on organizational effectiveness: A case study of the textile industry in Thailand. International Journal of Asian Business and Information Management, 7(3), 40-53. doi:10.4018/IJABIM.2016070103

Sohail, M. S., \& Daud, S. (2009). Knowledge sharing in higher education institutions: Perspectives from Malaysia. Vine, 39(2), 125-142. doi:10.1108/03055720910988841

Tam, C., \& Oliveira, T. (2017). Understanding mobile banking individual performance: The DeLone \& McLean model and the moderating effects of individual culture. Internet Research, 27(3), 538-562. doi:10.1108/IntR05-2016-0117

Teo, T. S., Lim, G. S., \& Fedric, S. A. (2007). The adoption and diffusion of human resources information systems in Singapore. Asia Pacific Journal of Human Resources, 45(1), 44-62. doi:10.1177/1038411107075402

Ulrich, D. (1997). Human resource champions: The next agenda for adding value and delivering results. Boston, MA: Harvard Business School Press.

Uppal, M. A., Ali, S., \& Gulliver, S. R. (2017). Factors determining e-learning service quality. British Journal of Educational Technology. doi:10.1111/bjet.12552

Voermans, M., \& van Veldhoven, M. (2007). Attitude towards e-HRM: An empirical study at Philips. Personnel Review, 36(6), 887-902. doi:10.1108/00483480710822418 
Wei, K.-M., Tang, Y.-T., Kao, Y.-C., Tseng, L.-C., \& Wu, H.-H. (2017). Using an updated Delone and McLean model to assess the success of implementing the ward cleaning logistics system in a medical center. Journal of Statistics and Management Systems, 20(5), 965-976. doi:10.1080/09720510.2017.1338609

Weijters, B., Cabooter, E., \& Schillewaert, N. (2010). The effect of rating scale format on response styles: The number of response categories and response category labels. International Journal of Research in Marketing, 27(3), 236-247. doi:10.1016/j.ijresmar.2010.02.004

Wiblen, S., Grant, D., \& Dery, K. (2010). Transitioning to a new HRIS: The reshaping of human resources and information technology talent. Journal of Electronic Commerce Research, 11(40), 251-267.

Wu, J.-H., \& Wang, Y.-M. (2006). Measuring KMS success: A respecification of the DeLone and McLean's model. Information \& Management, 43(6), 728-739. doi:10.1016/j.im.2006.05.002

Yu, C. S. (2015). Antecedents and consequences of trust in using mobile banking. MIS Review: An International Journal, 20(2), 27-56.

Zviran, M., \& Erlich, Z. (2003). Measuring IS user satisfaction: Review and implications. Communications of the Association for Information Systems, 12(7), 81-103. 


\section{APPENDIX: SURVEY ITEMS}

Information quality (IQ)

IQ1. The HRIS output is presented in a useful format.

IQ2. The HRIS provides me with the information at the time I need it to manage my performance.

IQ3. The HRIS provides information that is clear to me.

IQ4. The HRIS provides me with all the instructions that I need.

System quality (SQ)

SQ1. The HRIS is easy to use.

SQ2. The HRIS has good interactive features.

SQ3. The HRIS responds quickly.

SQ4. The HRIS works well.

SQ5. The HRIS has not had technical problems.

Help desk service quality (SR)

SR1. The help desk of HRIS is prompt in responding to my queries.

SR2. I can speak with a help desk representative in case I have problems with the HRIS.

SR3. When I log into HRIS I feel secure that the system instils confidence in me.

SR4. The help desk representatives understand the needs of HRIS users.

Situation normality (SN)

SN1. I am totally comfortable working with the HRIS.

SN2. I feel very good about how things go when I use the HRIS.

SN3. I always feel confident that the right things will happen when I use HRIS.

SN4. It appears that things will be fine when I utilize use HRIS.

Structural assurance (SA)

SA1. The HRIS has enough safeguards to keep my performance data private.

SA2. I feel assured that technological structures in HRIS adequately protect me from problems

(e.g. unauthorised person viewing my performance data) with the HRIS.

SA3. I feel confident that technological advances of HRIS make it safe as a secure site for me.

SA4. In general, the HRIS is now a robust and safe system to store my performance data in it.

User satisfaction (US)

US1. The HRIS is of high quality.

US2. The HRIS has met my expectations.

US3. My interaction with the HRIS is very satisfying.

US4. Overall, I am satisfied with using the HRIS.

Strategic benefits

PB1. I feel HRIS aids in implementing our faculty/school strategies effectively.

PB2. I feel HRIS helps to define our faculty/school strategies.

PB3. I feel HRIS helps us to fulfilling our faculty/school strategic goals.

PB4. I feel HRIS helps us to align human resource strategies with our faculty/school strategies. Administrative benefits

PB5. I feel HRIS supports the HR processes in our faculty/school.

PB6. I feel HRIS improves productivity by reducing the cycle time of administration processes in our faculty/school.

PB7. I can monitor the administrative processes of my performance in the HRIS efficiently.

PB8. I think administration process (e.g. documentation, workflow etc. of my performance) have been improved by using the HRIS.

Change and transformation benefit

PB9. I feel HRIS takes part in initiating change in our organisational culture.

PB10. The HRIS helps me to adapt to changes and issues in my faculty/school.

PB11. I believe the HRIS helps to make changes happen in my faculty/school.

PB12. I feel the HRIS actively participates in our organisational renewal, change and transformation. 
Employee's contribution benefit

PB13. I believe the HRIS improves the level of my commitment to the faculty/school and university.

PB14. I feel the HRIS policies respond to my personal needs.

PB15. I feel the HRIS helps me to meet my personal needs.

PB16. The HRIS is designed in a way to care about my personal needs.

Ashkan Davarpanah is a senior information technology (IT) sales consultant in a business process outsourcing (BPO) organization based in Malaysia. Ashkan holds a Master of Business Administration (MBA) in Strategic Management from Universiti Teknologi Malaysia. Ashkan's research interests include adoption and management of IT, trust in IT, mobile technologies, and Internet of Things. Ashkan has previously published a conference paper on Human Resource Information Systems (HRIS) success factors and leadership dimensions in an IT contact centre.

Norshidah Mohamed is currently Associate Professor of Management Information Systems and Operations Management at Prince Sultan University in Riyadh, Kingdom of Saudi Arabia. Dr. Norshidah has both industry and academia experiences. Prior to joining the academia in 2004, she spent more than 10 years in Malaysian financial and information technology industries. Dr. Norshidah has authored an edited book published by IGI Global in the USA. Besides, she has published almost 100 papers in local and reputable international refereed journals and conferences. This includes in Computers in Human Behavior, Industrial Management \& Data Systems, Information Management and Computer Security, Campus-Wide Information Systems and, Journal of Information Technology Research. She is also a certificate recipient of the Harvard Business School Alumni Club of Malaysia for the 2013 Senior Management Development Program. 